
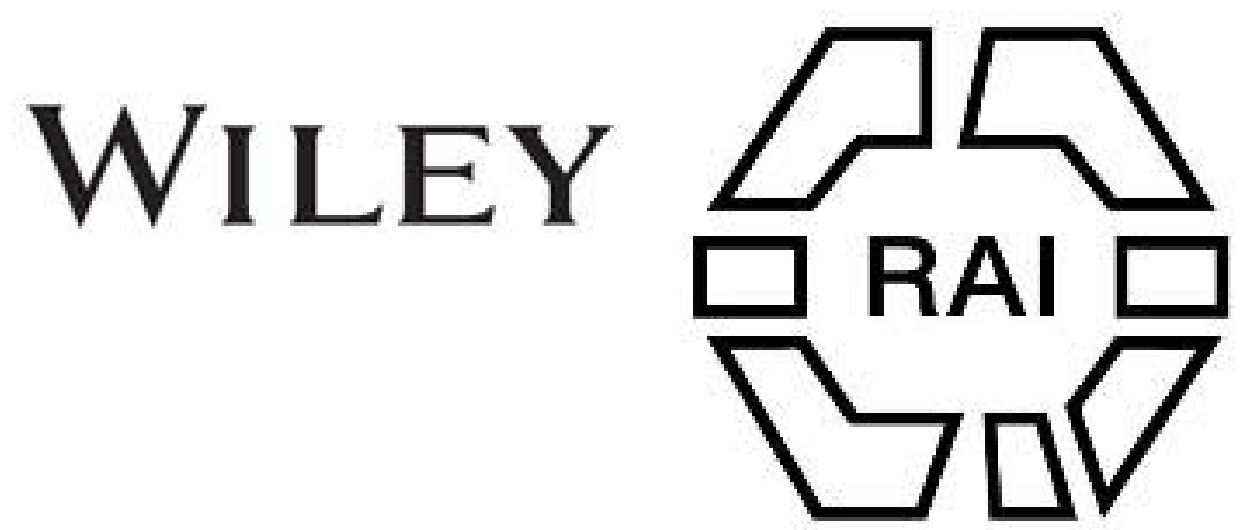

Some Eoliths from Dewlish, and the Question of Origin.

Author(s): C. J. Grist

Source: The Journal of the Royal Anthropological Institute of Great Britain and Ireland, Vol. 40 (Jan. - Jun., 1910), pp. 192-208

Published by: Royal Anthropological Institute of Great Britain and Ireland

Stable URL: http://www.jstor.org/stable/2843149

Accessed: 27-06-2016 07:29 UTC

Your use of the JSTOR archive indicates your acceptance of the Terms \& Conditions of Use, available at

http://about.jstor.org/terms

JSTOR is a not-for-profit service that helps scholars, researchers, and students discover, use, and build upon a wide range of content in a trusted digital archive. We use information technology and tools to increase productivity and facilitate new forms of scholarship. For more information about JSTOR, please contact support@jstor.org.

Wiley, Royal Anthropological Institute of Great Britain and Ireland are collaborating with JSTOR to digitize, preserve and extend access to The Tournal of the Royal Anthropological Institute of Great Britain and Ireland 


\title{
SOME EOLITHS FROM DEWLISH, AND THE QUESTION OF ORIGIN.
}

\author{
By C. J. Grist, M.A.
}

[With Plates XX, XXI.]

THE worth of the Eolithic problem depends very largely on the help it can bring to the task of tracing the history of the human race to its beginnings. It is, therefore, unfortunate that the geological age of the typical eolithic drifts of this country cannot be fixed with certainty. The question of the age of an eolith has become entangled with the question of its origin; and the trend of discussion has been to seek a geological solution for every difficulty.

This, I think, makes it desirable to draw a distinction. The question of the age of an eolith seems to me to resolve itself into a consideration of the condition of a piece of flint, and its geographical environment-a geological question, purely and simply. The question of its origin-whether certain chippings are, or are not, the product of a primitive industry-necessitates our taking the mind of primitive man into consideration, as well as geological data.

The eoliths to which I invite attention in this paper lend themselves very readily to this method of treatment. They were found in close association with the Elephas meridionalis deposit of Dewlish in Dorsetshire-described in the Memoirs of the Geological Survey as "undoubtedly of Pliocene age." Accordingly, the paper is divided into two parts.

\section{Are the Eoliths of Pliocene Age?}

(a) The Deposit.-The Pliocene deposit of Dewlish is situated in a fissure or trench measuring about 100 feet long and 12 feet deep, which crosses obliquely the summit of a narrow chalk ridge. This ridge runs in a north-south direction. The east side of it slopes gently towards a dry valley; the west forms a steep scarp descending to a brook a hundred feet below. Some hundred yards to the north of the trench (i.e., in the direction of the highest ground of the county) there is a wide and shallow depression. The deposit may be said, therefore, to occupy a singularly isolated position.

The two slopes of the ridge differ in character as well as in contour. That on the east is capped with loam and utilised as plough land; the scarp is covered with grass, through which the bare chalk can be seen in several places. A banked up hedge runs along the crest, forming a boundary between the grass

1 Pliocene Deposits of Britain, p. 206. 
slope and the plough field, and, as a consequence, the trench is divided into two parts, to which I will refer later on as the scarp pit and the field pit.

The earliest notice of the deposit takes us back to 1814 . In the Monthly Magazine of that year, a Mr. Hall records the discovery of some elephant remains on the scarp side of the hedge. I quote one paragraph of his paper:- "There is a hill in the parish of Dewlish which was always supposed to be formed of chalk; only but last summer, about 100 feet above the level of the foot of the hill, some sand was observed to be drawn out by a mouse."

Nothing further seems to have been observed till 1883, when an elephant molar was found at the same spot by Mr. Kent (senior). In 1887, Mr. Mansell Pleydell and the Rev. O. Fisher interested themselves in these finds, and made an excavation on the scarp. Then it was the trench and the true character of its contents came to light. On a subsequent occasion they opened up the trench on the plough field side of the hedge, and found that it terminated in an "apse-like end." A description of these excavations, together with various theories as to the origin of the trench, is given in the Quarterly Journal of the Geological Society, and also in the Geological Survey Memoirs." Mr. Mansell Pleydell says:- "A very remarkable circumstance is that there is not a trace of a gravel terrace or the slightest outward indication of the existence here of anything but chalk." This is noteworthy, for it emphasises what I have already twice mentioned-the isolated position of the deposit, and makes it clear that in solving the question of the age. of the eoliths we shall not be hampered by any hypothesis of later drifts.

The nature of the contents of the trench will be seen by the sections given.

Mr. Hall's section :-

Feet.

1. Chalk $\ldots \quad \ldots \quad \ldots \quad \ldots \quad \ldots \quad \ldots$ about 3

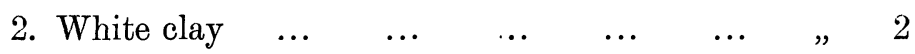

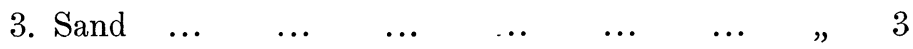

4. Chalk $\begin{array}{lllllllll} & \ldots & \ldots & \ldots & \ldots & \ldots & \ldots & \# & 2\end{array}$

5. Gravel with large flints $\quad \ldots \quad \ldots \quad \ldots \quad$, $\quad \ldots \quad 3$

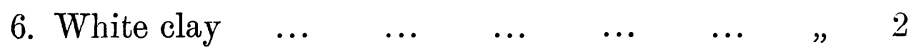

$\begin{array}{lllllllll}\text { 7. Chalk } & \ldots & \ldots & \ldots & \ldots & \ldots & \ldots & \# & \text { ? }\end{array}$

Mr. Mansell Pleydell's section :-

Feet. Inches.

$\begin{array}{llllllllll}\text { 1. Mould } & \ldots & \ldots & \ldots & \ldots & \ldots & \ldots & \text { about } & 0 & 3\end{array}$

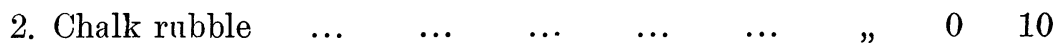

3. Fine impalpable sand and flints. Remains of elephant $\begin{array}{lll}3 & 0\end{array}$

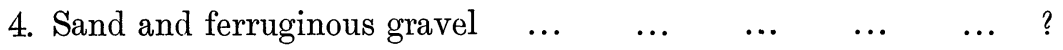

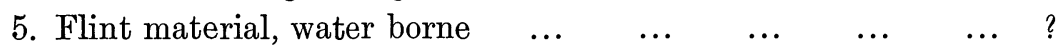

6. Sand, the lower portion with different sized flints $\quad \ldots \quad \ldots$ ?

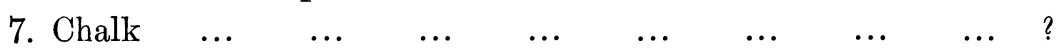

1 Quarterly Journal, Geological Societu, 1888, 1905.

2 Memoirs Geological Survey, Dorchester ; Proceedings, Dorset Field Club, 1904.

VoL. XL. 
The Rev. O. Fisher, in his notes on the scarp pit, says:- "Angular gravel impacted in an extremely fine sandy silt; and in this were numerous fragments of ivory, disseminated, forming a constituent part of the gravel much as other stones do. Towards the bottom of the deposit I found the gravel much coarser and subangular, and here I met with a portion of a nearly worn down molar . . . and some curiously polished flints."

The trench has yielded in all :-

Nine molars, with numerous isolated plates of others,

Several limb bones,

Several tusks and much scattered ivory. In some places the fragments of ivory were so numerous as to predominate over the other materials.

(b) The Eoliths.-Early in 1906 I happened to be within a few miles of Dewlish, and out of curiosity walked over to see the deposit. On enquiring for the Elephant pit, as it is called in the village, I was told it was at the top of the chalk bank. There was little to locate its whereabouts, for it had been filled in again. I saw a few iron-stained flints in the turf, and that was all.

I struck homewards across the plough fields of the ridge, and there I noticed that while the surface in general consisted of loam with black and white flints, the corner near the hedge was thickly strewn with coarse, angular flints of a peculiar orange colour. These attracted my attention, because the colour matched exactly with that of the flints at the scarp pit on the other side of the hedge. After examining the spread more closely I lighted upon four eoliths. Though appearances connected them with the "Elephant pit," I was much puzzled to account for their presence on the surface of the plough field. (I was not at the time acquainted with the details of the excavations.) To clear up the difficulty I "consulted the workman who had been employed by Mr. Mansell Pleydell. He is the gravel digger and road contractor of the village, and knows the ground "for miles round." He told me that after the work of exploration had been completed most of the material from the trench was put back again; the remainder was spread upon the surface of the plough field. Hence the patch of orange-stained flints by the hedge. For confirmation, he picked up several flints and pointed out the fractures which had been made by the pickaxe when he "grubbed them out of the concreted stuff in the.pit." Mr. Kent, whom I consulted with later on, was equally decisive as to their origin; and he lives within sight of the pit, and farms the land on which it is situated.

There is a woodcut in the Memoirs of the Geological Survey which shows the position of the deposit quite clearly. It gives the open trench in the field, close to the hedge, as it appeared during the excavations of 1887. It is just at this place where the orange-stained flints are most abundant at the present time. On a subsequent visit I found two more eoliths in the same spread.

I think there was reason to believe that all these eoliths were associated with 
the trench. However, one of them-a flake-was paler than the rest, and quite white along the edge, which pointed to a possibility of a mingling of surface material with trench material. To eliminate this source of doubt I arranged, through the courtesy of $\mathrm{Mr}$. Kent, to open the trench in the following spring (1907), and selected for the purpose the scarp portion, for there the capping of turf and the intervening hedge and bank had formed an effectual barrier against recent drift from the plough field. Any ferruginous gravel met with in the scarp pit must have formed part of the original undisturbed deposit. On that point there is no room for doubt.

In order to fix upon the most likely spots for sampling the contents of the trench, and to become better acquainted with details, I secured the assistance of the workman referred to above. At a later date (August, 1908) more holes were dug in this pit.

To put the results briefly:-

(a) I found eight eoliths in the trench among the ferruginous flints.

(b) The general appearance of the contents of the trench confirmed the belief that the eoliths found previously in the field had been derived from the deposit.

(c) Some of the ferruginous flints of the trench had been deprived of their staining.

These results, viewed in the light of the 1887 sections as given above, lead me to conclude that the eoliths are undoubtedly of Pliocene age.

With reference to the staining, I may add that I have since met with scraps of flint drift carrying the same peculiar orange stain in the lowlands well beyond the chalk escarpment; -in Dorset, in Hampshire (between Alton and Selbourne), in Sussex (at Berwick), and in Kent (at Ightham). I have also met with stray bits on the chalk in Hampshire (above Ropley), in Wiltshire, and near Terry's Lodge on the Kent plateau. It is noteworthy, too, that one of the molars from the Dewlish scarp pit, now in the museum at Cambridge, is marked with this orange stain.

The stain varies in strength considerably. Occasionally it is very weak, which suggests decoloration. As an experiment I placed a few specimens in a 1 per cent. solution of oxalic acid, and some others in a 2 per cent. solution. In four months the latter became almost white; the former lost colour, but not so much. Oxalic acid was chosen as being a rough and ready approach to the action plant acids.

\section{The Question of Origin.}

I must here offer a few words of explanation. When the field eoliths were found there was a good deal of uncertainty in my mind as to their origin. They bore some resemblance to the eoliths of Kent, and the chipping was accepted as 
human work by Mr. Harrison and Mons. Rutot. On the other hand there was at the time, both in England and France, a strong outburst of objection against eoliths in general. Pre-paleolithic chipping, it was urged, could be attributed to natural causes. Under these circumstances it seemed desirable to look at both sides of the question in the light of a to-and-fro searching among nature's handiwork and man's. This part of the paper is the outcome; and I have accordingly arranged the matter under the sub-headings of Natural Causes and Human Work.

\section{A. The Theory of Natural Causes.}

1. The origin of the distinction between paleolith and pre-paleolith can be traced to the classification put forward by Mortillet, in the year 1869. ${ }^{1}$

At that time, attention was focussed upon cave deposits, and river drifts of the Somme valley type. With the single exception of the flints submitted by Bourgeois, in 1867, there was not in evidence even a vestige of an earlier industry. Mr. Harrison's plateau flints were not put forward till some twenty years later, and it was not till then the term eolith came into use.

Mortillet says ${ }^{2}$ :- "At the base of the quaternary deposits man's industry

. . . is reduced to a single instrument which is at the same time a weapon and a tool-C'est l'instrument primitif. This primitive instrument, the most ancient witness of the existence of man . . . is the coup-de-poing."

And the coup-de-poing thus became our base line of the Paleolithic age.

There is proof enough now in our museums that this confident language was unwarranted. The coup-de-poing is too cleverly worked and too widely distributed to be any longer accepted as the type of the "primitive" instrument of the human race. We must accept it, I think, as a standard pattern in paleolithic industry-reached through pre-paleolithic types and by pre-paleolithic efforts.

2. It is urged ${ }^{3}$ :- " There is no reason to conclude that pre-paleolithic man lived in this region of the world . . . paleolithic culture may have been introduced ready made from more southern areas." "Perhaps in Pliocene times our first ancestors occupied some other part of the globe more or less distant from the Europe of to-day." "Eoliths are a-typiques" and should not be accepted as archæological documents "unless they are accompanied by some well-established certificate of origin, e.g., un foyer, une sépulture, un atelier," etc.

All objections of this kind run counter to every-day experience; and also to an order of procedure which has the warrant of historical evidence. We do not, as a rule, search for our burglar before we have evidence of his handiwork. Similar objections were raised sixty years ago, and in much the same language, against paleoliths and paleolithic man. "Everything leads us to believe," said Cuvier,"

1 Le Préhistorique, G. et A. Mortillet. Paris edition, 1900. Preface.

2 Ibid., p. 131.

3 Journ. Anthrop. Inst., vol. xxxv, 1905, p. 327 ; Dechelette, Manuel d'Archéologie Prehistorique, Paris, 1908, p. 32.

${ }^{4}$ Cuvier, Discours sur les Révolutions du Globe, ed. Didot, 1858, p. 86. 
with reference to the researches of Boucher de Perthes, "that the human species did not exist in the area . . . I do not wish to conclude that man did not exist at all . . . he night have inhabited some other parts of the world from whence," etc.

Boucher de Perthes' pieces of evidence were the neoliths from the tourbières. In these he recognised work which postulated earlier efforts. Had he waited for certificates of origin, in all probability the world would still be in ignorance of his discoveries.

Our eolithic problem is in a very similar position to-day.

3. We are told that eoliths are sometimes found in paleolithic drifts; "which breaks down the argument for a pre-paleolithic age," and indicates natural origin.

Let us recollect that paleolithic drifts are the outcome of accumulations and redistributions extending over long geological periods, during which valleys have been raised and depressed; during which, too, running water, carbon dioxide, chalk, and organic acids may have influenced the mineral conditions of a fractured flint quite as much as iron and manganese. I have in mind here the state of things in the Thames valleys, where paleoliths can be found in association with quartzites and greensand chert, eocene pebbles and chunks from the chalk downs, and fractured flint in all sorts of mineral conditions. I have in mind also the drifts of the Isle of Wight, where beheaded valleys are numerous. With surface drifts and surface finds on high ground the contention is still more illusory. We have but to go to Central France to find paleoliths in association with neoliths. Mortillet ${ }^{2}$ tells of one district in the Vienne where paleoliths have been picked up by hundreds on the surface of the soil ; of another, in the Allier, where thousands have been turned up by the plough. At Pontlevoy, he says, the peasants used to take their little bags of silex taillés to market, along with the other produce of their fields. Near Sarlat in the Dordogne, a baker used to set out with his cart full of loaves and return with it laden with stones. Mr. Harrison, himself, has never equalled that with his eoliths of the Kent Plateau.

Mons. Rutot, making reference to parcels of these surface implements sent on to him for examination, says ${ }^{3}$ :- “ Appearances are very deceiving. Chelleen, Acheuleen, Mousterien, are lamentably mixed up with the industry of the polished stone age. And if occasionally there seem to be signs-patine, polish, abrasionwhich promise a means of discrimination, we soon find ourselves at fault, for pieces evidently neolithic are met with carrying the very marks we had hoped to see reserved for the paleolithic."

If these are the difficulties encountered when paleoliths and neoliths occur together, to urge "association" as evidence for natural causes can only lead to confusion of ideas.

1 Journ. Anthrop. Inst., vol. xxxv, 1905. Man, April, 1908 ; September, 1909.

${ }^{2}$ Le Préhistorique, Mortillet : ed. 1900, pp. 571-575.

3 Bulletin de la Société Prehistorique de France, Av. Mai, 1908. 
4. For evidence of natural causes, as distinct from evidence of age, the theory relies mainly on the work of machines, which are obviously open to the preliminary objection that they are non-natural causes. With such ample opportunities as we have for discovering what nature can do, and has done, why should we have recourse to a hypothetical argument based on the work of a machine? This machine does so and so ; nature is more powerful than a machine; therefore nature can do likewise. Hence the eoliths.

Fortunately the validity of the argument can be tested by field evidence. Granted that nature makes eoliths, then eoliths will be found where nature satisfies the conditions laid down. And since nature does not confine her operations to any particular age, they will be found as readily where we believe primitive man cannot have been present, as where, in paleolithic drifts for instance, we have traces of his presence. And not in flint drifts merely; for the eoliths of Tasmania and South Africa are of different material.

"Field evidence," says Mr. Warren," our foremost exponent of Natural Causes, " has no bearing on the question at issue . . . It is a knowledge of the fracture of flint under different conditions that we require." With this I disagree; for, surely, it is quite possible for the conditions determining a fracture to be the same whether nature or man exerts the pressure or strikes the blow. For example,-a man may obtain an eolithic fracture, or a paleolithic, by throwing pebbles about, on a sea beach; nature, too, when the wind blows a gale. There is an excellent imitation of a paleolith in the Cambridge Geological Museum, which is said to have been made by nature on the beach near Sheringham.

To say field evidence has no bearing on the question at issue, seems to me to ignore nature's own evidence of her handiwork. To say that a knowledge of the fracture of flint will decide the issue is to ignore the evidence of design, which is the distinguishing feature of the work of man.

5. Mr. Warren is of opinion ${ }^{2}$ that eoliths may be produced by pressure: in soil creep, the foundering of drifts, the stampeding of animals, etc. I will mention a few places where one may find, in plenty, naturally fracturel material with clear evidence of creep and pressure :-The talus of chalk pits, the scarp drift of chalk hills, the pipes in the railway cuttings between Alton and Alresford, the valley bottom at Candover, the flint beds on the hill above Teignmouth, the Permian débris at Shaldon, the shingle beach between Langney point and Cooden, the chalky gravel near the railway line facing Boxhill, the broken flint beneath the loess on the chalk plateaux west of Evreux, the flint débris capping the cliffs at Ste. Adresse. I have searched for typical eoliths in these places and have found nothing to lend credence to any theory of Natural Causes.

One other place may be mentioned-Newlands Corner, in Surrey. There, close to the scarp ridge of the Downs, we have an extensive deposit which is worked

I See Mr. Warren, Journ. Anthrop. Inst., vol. xxxv, 1905.

2 Ibid. 
to supply road material. It consists of a medley of clay, and sand, and flints of all sizes from small eocene pebbles to brecciated masses two feet in diameter, and a sprinkling of greensand débris. It appears to be an old sludge deposit, for it has points of resemblance with the muddy masses one sometimes sees in the Alps near the snowline, or by the foot of the cliffs in the Isle of Wight and at Cromer. Stones stand upright in clay, there are traces of former stream action within the mass, and there is a trailing of gravel leading into the valleys below. If the deposit were in the North of England it might pass for a patch of Boulder Clay. Whatever the origin, it is certainly the sweepings from higher ground no longer existing.

During the gradual removal of this deposit, extending now over many years, the sections have exposed innumerable examples of foundering and squeezing. Sometimes I have seen the pieces of a flint that has been fractured by pressure lying separated by half an inch of sand or clay; but never among the pressure fractures an eolith. The nearest approach to human work was found on two rolled flints that had not been chipped within the deposit.

These resemble, somewhat, a paleolith found at Knowle Hill farm.

6. With regard to stampeding, ${ }^{1}$ we may ask:-Of the thousands of neoliths picked up on our chalk downs, carrying in their rust marks evidence of pressure by the plough or horses' shoes, how many can be said to bear out this contention? True, a notched flint is often found, but it usually cuts the hand of anyone who uses it.

7. The action of sea waves is less likely still to be the cause $;^{2}$ for every eolithic flint on a beach is accompanied by myriads of well-formed pebbles. And this being so, how is the absence of pebbles to be explained, say, for example, in the eolithic spread on the Kent Plateau, where mineral conditions may be taken as a guide?

8. Across the Channel, the case for natural causes rests mainly on the observations made by Mons. Marcellin Boule in the cement mills of Mantes, the inference being that eoliths may be produced by torrent action.

Mons. Boule says ${ }^{3}$ :- " To eliminate the flints from the chalk sludge, the water is put in movement by a horizontal wheel to which are suspended cast-iron harrows plunged to within $2 \mathrm{c}$ cm. from the bottom. The wheel, five netres in diameter, makes sixteen turns a minute; and the speed near the circumference is therefore about four metres a second." "Among the flints withdrawn at the close of the operations may be found certain specimens which might be taken to be the result of finished workmanship with retouches methodical and several times repeated." Flints have been found recalling, grossièrement, scrapers of Magdalenien type and even notched flakes of neolithic appearance. ${ }^{4}$

1 See Mr. Warren, Journ. Anthrop. Inst., vol. xxxv, 1905.

${ }^{2}$ Sir John Evans, Congrés Prehistorique.

3 L'Anthropologie, Paris, 1905.

${ }_{4}$ Manuel d'Archéologie, Dechelette, p. 30. 
In examining this statement we have three factors to consider:- $(\alpha)$ the sludge; $(b)$ the speed; $(c)$ the harrows.

(a) Natural sludge streams move slowly, even where the gradient is steep : for the reason that the carrying of the load consumes the greater part of the energy of the flowing water. A natural sludge stream with a speed of four metres a second may therefore be dismissed at once as a physical impossibility.

(b) In a river, the velocity of the current depends chiefly upon the gradient and the volume of water, and the transporting power of the current varies as the sixth power of its velocity. With a central surface current of two feet per second, the bottom current would be quite able to move sand.

Now M. Boule is of opinion" that "the torrential force of the immense quaternary rivers must have been greater than four metres a second." He has in mind no doubt the rivers rising in the plateau between Mons and Lille. Here, neither the appearance of the eoliths nor the gradient of the river beds is suggestive of torrential force answering to M. Boule's description.

(c) The iron harrows have a regular outline; are rigidly fixed to a frame; revolve with uniform velocity along the same course; and strike against stones suspended in the load, with some degree of regularity ; an assemblage of conditions not met with in a river. There, the shocks are caused by stones irregular in outline; movement is spasmodic, and uncertain in direction, because of cross currents in the cailloutis, and the friction of the bed. Moreover, the striking stone is checked in its course by the stone which is struck, and there is a tendency to revolve after the impact. In brief, the chances of regularly distributed blows as against fortuitous shocks must be very remote indeed.

The imitations of Magdalenien and neolithic scrapers included in the flint residue emphasise the non-natural character of the work. It is further emphasised by the results of some experiments carried out in the Ardennes, ${ }^{2}$ where an eolithic spread has been found intact under the peat capping of Hautes Fagnes. Messrs. Munck and Ghilain working independently have found that the torrents rising in the plateau cause eoliths to lose their characteristics by the time they have travelled two or three kilometres.

9. Let us now approach this question of river action from the opposite point of view.

It must be admitted, if river action is indeed capable of producing eoliths, that eoliths will be found in all river gravels, and in number bearing some ratio to the volume of the gravel. A section of river gravel over 600 yards long and 10 to 18 feet high should therefore supply a considerable quantity of eoliths.

\footnotetext{
1 L'Anthropologie, Paris, 1905.
}

2 Congrés Préhistorique de France, 1907. 
Such a section may be seen at Kingston Hill. This gravel working stands, at 178 O.D., on a thin remnant of the Bagshot sands, well above the paleolithic terraces, and well out of reach of the brick earths and other complications. It is true river gravel, with much current bedding, and forms part of the Old Thames bed. Rarely have I found here any fractures suggestive of human work. On the contrary, a comparison of characteristic samples of the gravel with the eoliths of M. A. Rutot and Mr. Harrison and with these from Dewlish, shows that river action tends to obliterate eolithic features. This is made all the more apparent by examining the surfaces of the flints at various points of the section. At the south end, for instance, gravel gives place to sand, which implies a slackening of the current and the probable presence of a backwater. Here the workmen have found blocks of tuberous flint which appear to have been torn bodily from the chalk, and afterwards carried down the stream for at least the distance separating Kingstcn Hill from the Surrey Downs, presumably by ice or by the roots of trees. The fracture surfaces on these blocks are all clean cut and sand polished, without any sign of pounding. Fracture surfaces of a corresponding origin which are found in the gravel are almost invariably bruised and battered.

10. I will close this part of the paper with a reference to the Alderbury gravelsso often held to confirm the theory of natural causes. ${ }^{1}$

These gravels cap a hill (325 O.D.), and the working sections run across it. On the west there is a steep descent to the Avon Valley 160 feet below ; on the east a descent towards Dean. The high ground away north and south is completely cut off by wide transverse depressions. Beneath the deposit is a buffer of tertiaries.

What is the origin of the gravels?

The north section when I saw it first had the appearance of being river gravel. One seldom sees clearer traces of river action in low-level deposits. The paleolithic gravels of Knowle Farm offer a decided contrast in this respect.

Midway down the section, and crossing it horizontally, was a seam of pale clay where signs of river action were very distinct-stones, sand, and clay being beautifully graded. Below the seam there was also evidence of grading. Above it grading was not apparent, and there were festoonings; but this is often the case in the upper parts of old river gravels. In the Somme Valley festoonings are very conspicuous.

At a later date (January 3rd, 1907) I made the following notes of two portions of this section:-

Feet. Inches.

$\begin{array}{lllllllll}\text { (1) Black loamy soil } & \ldots & \ldots & \ldots & \ldots & \ldots & \text { about } & 1 & 0\end{array}$ $\begin{array}{llllll}\text { Angular gravel (grading not traceable) } & \ldots & \ldots & \ldots & 4 & 0\end{array}$ $\begin{array}{lllllllll}\text { Yellowish clay } & \ldots & \ldots & \ldots & \ldots & \ldots & \# & 0 & 4\end{array}$

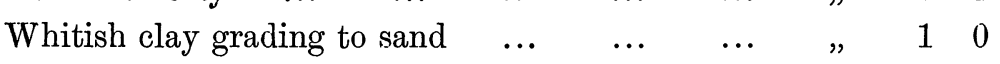
Gravel, dark red in colour; well graded $\quad \ldots \quad \ldots \quad 5 \quad 0$

1 Journ. Anthrop. Inst., vol. xxxv, 1905 ; Man, April, 1908. 
(2) Black soil ... Feet. Inches.

$\begin{array}{lcccccccc}\text { Black soil } \ldots & \ldots & \ldots & \ldots & \ldots & \ldots & \text { about } & 1 & 0 \\ \text { Angular gravel (grading not distinct) } & \ldots & \ldots & » & 4 & 0 \\ \text { Whitish clay } \quad \ldots & \ldots & \ldots & \ldots & \ldots & , & 1 & 0 \\ \text { Sandy clay and sand } & \ldots & \ldots & \ldots & \ldots & , & 0 & 6\end{array}$

Gravel, dark red, well graded : stones lying with Talus their long axes, horizontal $\ldots \quad \ldots \quad \ldots \quad \ldots \quad$, $\quad \begin{array}{lllll}4 & 0\end{array}$

There were little funnel-shaped pockets along the clay and sand band, which indicated by their contents that they had been formed at the time the clay was deposited by the stream, thus precluding any hypothesis of subsequent foundering of the underlying gravel. Sagging on the east and west edges of the section was very probable.

Dr. Blackmore tells me eoliths occur at various and uncertain depths. The very dead white, unstained ones come from the seam of clay.

In May, 1908, work had been stopped on this side and the face was hidden with talus. The opposite face showed river gravel of a dark red colour.

11. We have then, at Alderbury, to account for the presence of eoliths in the gravel of a river far older than the Avon and the Test. We have, also, to recollect that paleoliths and pleistocene remains are abundant low down in the valleys of these two rivers. We cannot but conclude that the Alderbury eoliths, especially those from below the clay seam, are very decidedly pre-paleolithic.

Turning to what has been said of Alderbury in support of the theory of natural causes we find :-

(1) Prof. McKenny Hughes looks upon the deposit as an example of soil creep and foundering from higher ground, and suggests that the eoliths may have been formed by pressure, etc., in the process. ${ }^{1}$

(2) Mr. Warren adopts this explanation and adds:-_" It is interesting to note that many of the eoliths found here show little or no signs of water abrasion."2

(3) Mr. Worthington Smith, who has stated frequently and emphatically that human work of a Pre-paleolithic age does not exist, says of one Alderbury eolith sent to him for examination:- "This is a good bulbed flake with very skilful lateral paleolithic flaking." Of another, "a still finer piece work doing duty as eolith in the Blackmore Museum."3

12. The question may arise:-What is the origin of the theory? On this point the history of the movement is very suggestive.

'The objections now urged against eoliths and eolithic man were urged fifty years ago against paleoliths and paleolithic man, as the following phrases used at

1 Proceedings Cambridge Philosophical Society, vol. ix, Part II.

2 Journ. Anthrop. Inst., vol. xxv, $1905 . \quad{ }^{3}$ Man, April, 1908. 
the meetings of the Paris Anthropological Society in the year 1860 will testify ${ }^{1}$ :"Need of positive proof; land slips; considerable number of flints in one place; striking together of neighbouring flints in the same torrent; flakes knocked off by a workman's pick; fortuitous shocks ; rolled flints."

It is evident that the theory of natural causes was in existence at least. twenty years before the eolithic problem made its appearance.

\section{B. Are the Dewlish Eoliths of Human Origin?}

1. Let us glance for the moment at the process of flint flaking, as it is carried on to-day at Brandon.

A block of flint is quartered to obtain a fairly flat strike face. Then a series. of flakes is struck off round the sides of the quarter, then another, and so on till only a useless core remains. On the "outside" flakes we find (1) a fragment of" the strike face; (2) a smooth shell-like fracture springing from the point where the blow was struck; and, as a rule, (3) a slight splintering or esquillement near the point of origin of the fracture. The "insides" have the same characteristics, and in addition, (4) a concavity left behind by the previous removal of a flake.

By the constant repetition of this combination of marks we find it possible to say of a flint flake:-This is the product of human design and not the result of nature's fortuitous shocks.

Flints bearing these evidences of design are so numerous in our chalk districts that after awhile one is inclined to tire of giving them more than a passing notice. They are very common too in paleolithic gravel pits, where, save shapely specimens -fit companions for the coup-de-poing - they are usually cast aside as lumber.

2. They may on the contrary lead us to wonder what is the date of origin of the flaking industry. Taking this latter course, which is the course I wish to. follow up here, we search among the classifications of the prehistoric. So far as I know, M. A. Rutot's is the only one that makes any reference to the matter. ${ }^{2}$

In his Quaternary industry the Chelleen coup-de-poing period is preceded by a. Strépyien period, and that by a Mesvinien, associated with Elephas antiquus, the data being supplied by the relative positions of the deposits in the valley of the Trouille.

M. Rutot says the Mesvinien is eolithic. Dr. Hoernes (Diluviale Mensch in. Europa $)^{3}$ and other authorities cited by him prefer to call it paleolithic, and Chelleen. Eolithic, or paleolithic, is quite immaterial to our purpose. It is, all the same, "human," and very early Chelleen, if not pre-Chelleen.

This Mesvinien industry includes a large proportion of flakes characterised by the same marks as our modern "Brandons." Though the work may be less skilful,.

\footnotetext{
1 See also Les Ancêtres d'Adam, Victor Meunier (Paris, Fischbacher).

2 Le Prehistorique dans l' Europe Centrale, Rutot.

3 Der Diluviale Mensch in Europa, Braunschwejg, 1903, p. 195.
} 
the number of flakes removes any supposition that they were produced otherwise than by people possessed of the knowledge of flaking.

3. How was that knowledge acquired? Primitive man was just as powerless to create the necessary "ideas," as modern man in the making of an aeroplane. For "Man's imagination does not create; it can only reproduce and combine its own experience." There was nothing in nature to suggest the pattern. On this score the rude inventors of the flake process compare not unfavourably with the scientists of the aeroplane.

4. Man could only have acquired the knowledge of the process through previous experience in flint chipping. And to judge by the complicated nature of the process, he must have been able at the time to think over his experience, and draw the inference that such a course would economise both time and material.

This, taking the mind of the child as our guide in the matter, he could not possibly have done had he not already passed through the early stages of mental development. It is an every-day occurrence to find boys, already expert in imitating a process, who are quite incapable of making a simple inference which would lead to an improvement upon it. Boys apart, our own experiences in flint chipping point to the same opinion. And with us there is not the added difficulty which the primitive savage had to overcome-effect of environment and force of habit.

It seems incredible, then, that man could have discovered the process of flaking had he not already gained considerable practice in the use of flint.

Such practice could only have been gained in areas where flint was ready to hand: and moreover in pre-paleolithic times.

5. The flakes were fashioned for the purpose of serving the daily needs, and these needs were not new. Hence we may look upon any signs of usage we happen to discover upon them-any frequent repetitions of some well-marked feature, for instance-as a clue to human work on flints of a pre-paleolithic age.

6. Man's chief need was water. Should we therefore find any well-marked paleolithic features many times repeated on flints of our pre-paleolithic gravels, we may say:-this is in all probability the work of man. If in the next place we find a marked absence of these features among the fortuitous shocks of nature, then, I think, we may go further, and say:-this is indeed the work of man. We may grant that it is quite possible for the shocks of nature to imitate on a fragment of flint some one feature of man's work ; that interpretation is no longer possible when we see the same features reproduced again and again in flint drifts which we have reason to believe are contemporaneous with man.

7. One of the commonest marks on paleolithic and neolithic flakes of the Brandon type is the concave notch. Mortillet found it so common that he named such flakes, in consequence, coche grattoirs. The notch is also common on coupsde-poing, both gravel derived and surface implements. I have seen it too on a strike-a-light of the last century. 
If we clutch one of these flakes or coups-de-poing in the way that best fits the right hand, the notch will be seen near the opposite end, more often than not on the left side.

One cannot very well imagine the purpose served by this notch to be peculiar to paleolithic and neolithic times. Close examination often reveals, within the hollow, signs of pressing and bruising, resembling the usage marks which will be seen through a lens on a modern chisel or pruning knife.

If, next, we try the experiment of using the notched flake, as we should a chisel or pruning knife, we become aware that the part held by the hand is well adapted to the purpose. If we attempt to use in the same way the notched flints which may be occasionally picked up in cart tracks and on the sea shore, we become aware of a difference in this respect.

The cause is not far to seek. On the former all projections which would have injured the hand have been carefully removed. The result is an " easy fit."

8. It is scarcely credible that we are not here faced with further evidence of design. And, since the need of adapting flint to the hand undoubtedly preceded the need of the flaking process, it would be but straining an argument to suppose that pre-paleolithic flints carrying both notches and " easy fits" are less likely to be human than natural.

9. Some paleolithic tools of coup-de-poing type are flattened on one face, convex on the other. They vary in size. I have two tiny specimens from early paleolithic deposits-one of them from Swanscombe. Mr. Cross, who has ransacked Swanscombe and Northfleet pretty well, has a number of different sizes. Roughly worked flints somewhat similar in shape can sometimes be seen in other gravel pits among the poor stuff the diggers cannot dispose of in the museum market.

10. The paleolithic coup-de-poing furnishes another opportunity of tracing design in the Pre-paleolithic age.

Among the delicately worked examples of the Acheuleen period there is a class which consists of flints tapered sometimes to a point, sometimes to a knifeend edge. Along with these there is occasionally to be met another type of implement, poignard in shape. An excellent example of this latter can be seen in the Museum at Brussels. It is very cleverly chipped all over, and whether the maker intended it to be used as such or not, undoubtedly it would have served as a convincing argument in time of quarrel.

In the Chelleen period we get similar implements, but of a rudimentary pattern, often simply a flint, which is easy to clutch at one end, and at the other is. chipped to a point or knife edge by a few blows skilfully delivered, and making almost equal angles with the long axis.

In very early paleolithic deposits the standard coup-de-poing becomes rare in proportion to the total number of worked flints. On the other hand flints. suggestive of the dagger type become more numerous; and these are usually long flints easy to hold at one end, and chipped at the other as if they had been struck 
repeatedly against some unyielding substance. For convenience in reference we can call them all percuteurs - the name by which some of them are known.

It would seem that the use of these flint percuteurs declined as the skill of paleolithic man progressed. Maybe the quartzite pebble took their place. But this is only conjecture, begotten of chipped fingers through using flint and quartzite pebbles indiscriminately, in gravel pits. The fact remains; these long flints chipped and tapered at the end opposite the clutch are very common in the earliest paleolithic deposits, and are there accepted by all as a type of human implement.

Flints of exactly the same type are also very common in eolithic gravels. The chipping is comparable. Hence it is scarcely credible that in the one case they are the result of human work, and in the other the product of fortuitous river action.

Side by side with these percuteurs and rude coups-de-poing of early paleolithic deposits we have a third type of tool, formed of a handful-sized flint worked to a point by a double notch. If, in an effort at classification, we endeavour to arrange specimens from these deposits under the heads of coup-de-poing, percuteur, and "double notch," we soon become aware that it is often impossible to draw lines of distinction. Often the three types blend into one, on one tool.

Here, again, we have a state of things paralleled in eolithic deposits. And again, it is scarcely credible that in the one case they are the result of human work and in the other the product of fortuitous pressure and blows. Reject these flints from the eolithic as nature's work and not man's, and we must at the same time, I think, reject a good deal from our collections that is labelled paleolithic. We cannot reject them without explaining why, as the skill of man progressed, the shocks of nature were of less avail ; nor without explaining why nature, so lavish with her chipping, at one end of a flint should be so sparing at the other. Nor can we reject them without refusing to see in the mind of the child the line of mental development pursued by the race, and at the same time assuming that Mortillet's paleolithic peoples had a source of knowledge outside the domain of evolution.

11. So far we have been concerning ourselves with the eoliths of European origin. It should not be overlooked that we have also to take account of eolithic deposits in other parts of the world. I will quote a passage from Stone Implements of South Africa, by J. P. Johnson, p. 2 (Leitjfontein):-

"This gravel consists mainly of subangular fragments of jasper-a material that has travelled a long way, the nearest source being the Asbestos Hills, some 30 miles west. While it apparently can only have been brought to its present position by water, it has no evident connection with any existing river, and is therefore probably of very great antiquity. The jasper has changed externally from its original dull brown colour to a yellowish brown, and acquired a high glaze and polish.

"Mixed with the gravel are quantities of much worn and highly glazed eoliths. A few of these are a little more advanced than the true eoliths, being made from 
artificially produced splinters, but they are a small minority. Otherwise the group is in every way identical with the typical assemblage met with in the early plateau drifts of Southern Britain."

On referring to Mr. Johnson's plates it will be found that in general appearance the eoliths tally with the eoliths with which we are here concerned. The notch-both single and double-is very pronounced.

12. The same remark applies equally well to the implements used till quite recently by the aborigines of Tasmania, and here, as may be seen by the specimens exhibited in London, Cambridge, and Brussels, the material is far from being of a flinty nature.

13. To sum up the matter, I take these Dewlish eoliths to be of human origin.

I fail to find upon them any suggestion of origin by stream action-there is no fortuitous pounding of the surfaces, or abrasion of the edges. The eolithic fractures exhibit no signs of that irregular splitting and crushing which characterises the products of fortuitous shocks, and of the squeezing of flint against flint in a steadily sinking mass. The difference between the eolithic chipping and that on the general run of the flints from the same deposit is marked. And since we may take it that the eoliths have been subjected to the same kind of natural pressure, within the deposit, as the rest of the flints, I consider this difference to be highly suggestive of non-natural action. The difference became very apparent after I had handled some hundreds of the flints on the spot. More so, after examining at home a weighty number which Mr. Kent had kindly collected and forwarded. It was further emphasised by an inspection of some chance fractures which had been caused by the opening up of the scarp pit.

In brief, the eolithic chipping can, I submit, be differentiated from fortuitous natural chipping.

On the other hand, when I look at the result of the chipping I find some of the eoliths bear a resemblance in size, in shape, and in details, to paleolithic pieces which would to-day be generally accepted as human implements. Human implements, because the frequent repetition of these points of resemblance is generally accepted as good evidence of adaptation to a purpose; good evidence of human design and human origin.

I find others clearly belong to well-known types found in the gravels of Alderbury and Laverstock, in the plateau drifts of the North and South Downs and Hackpen Hill, and also in South Africa and Tasmania. Granted, it is quite possible for the shocks of nature to produce points of resemblance on fragments of stone in these places; that interpretation of the origin of these types is not, I think, possible, seeing that they present a remarkable combination of features repeated again and again, on stones differing in texture, from deposits which differ in character, and are far apart.

No. 1 from the field.-A flake with beak-shaped notch in left top corner. It has lost much of the original stain on the smooth side; all of it along the edge, where it is quite white. 
No. 2 from the field.-A pebble-shaped flint; notched. The fractures show wave markings. Stain faded.

No. 3 from the field.-Double notched, and with a well-formed point. One notch made by blows struck in opposite directions. Back fits the hand well, except at one corner, where is a natural fracture of later date. A common Alderbury and Kentish type.

No. 4 from the pit.-Double notched; the left notch with a row of small parallel chippings. (4a was found the following day at the base of a pit in the gravels of the Frome Valley, near Moreton Station.)

No. 5 from the pit.-Notched. In section not unlike a flat-bottomed paleolith. Trimming along the edge. When clutched in the right hand the notch shows itself at the left top corner.

No. 6 from the pit.- It will be observed that pieces have been shaved off the back to give a better grip. At one end there are two notches with point between them. This feature can be matched on Tasmanian implements, also on early paleoliths. Mr. Snares, of Brandon, was able to match the "shaved" flakes from the waste in his workshop. ${ }^{1}$

No. 7 from the pit.-Percuteur type. A somewhat cylindrical flint, tapered at one end as if by knocking downwards against an unyielding substance. It fits the hand and the size is convenient for use. A glance at the different surfaces is sufficient to dispel any supposition of stream action.

No. 8 from the pit.- $(8 a$ and $8 b$ are from Kent.) Dr. Blackmore has found similar shapes at Laverstock. M. A. Rutot finds the form common in all eolithic industries, including S. Prest. It is a form also found in early paleolithic deposits. I have a neolith much like it. Mr. Johnson figures similar implements in his Stone Implements of South Africa.

No. 9 from the pit.-Apparently a hammer stone. Broad end worked to a. slightly convex shape, by numerous fractures recalling paleolithic work.

No. 10 from the pit.-A rough flake of flint chipped at the edges; common Kentish type. Very like some Tasmanian tools.

No. 11 from the field.-The chipping along the back is too evenly distributed to be ascribed to fortuitous pressure or blows.

1 Mr. Snares, the flint worker at Brandon, is of opinion the Dewlish eoliths are of human origin. 
Journal of the Royal Anthropological Institute, Vol. XL, 1910, Plate XX.

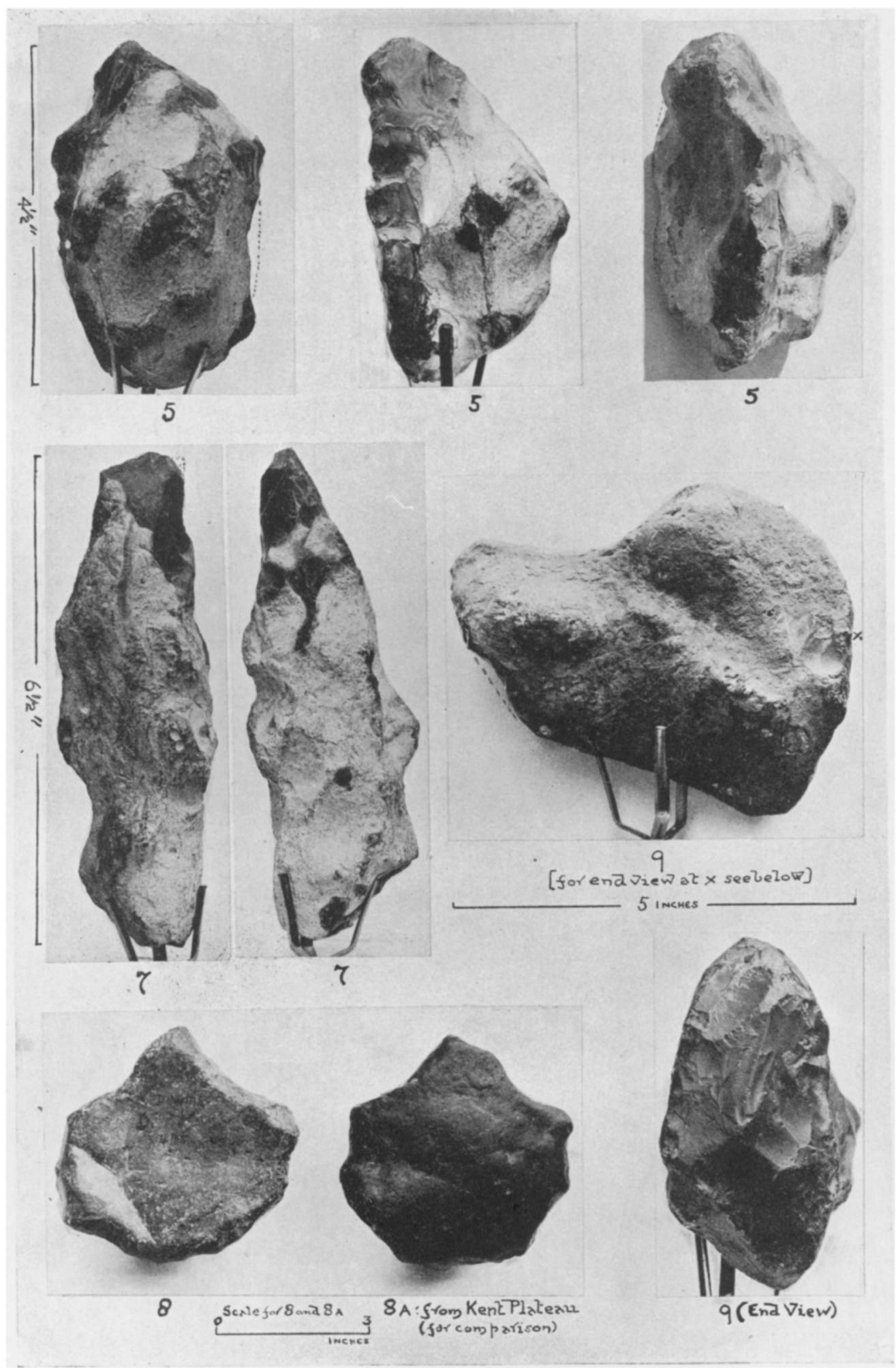

SOME EOLITHS FROM DEWLISH. All use subject to http://about.jstor.org/terms 


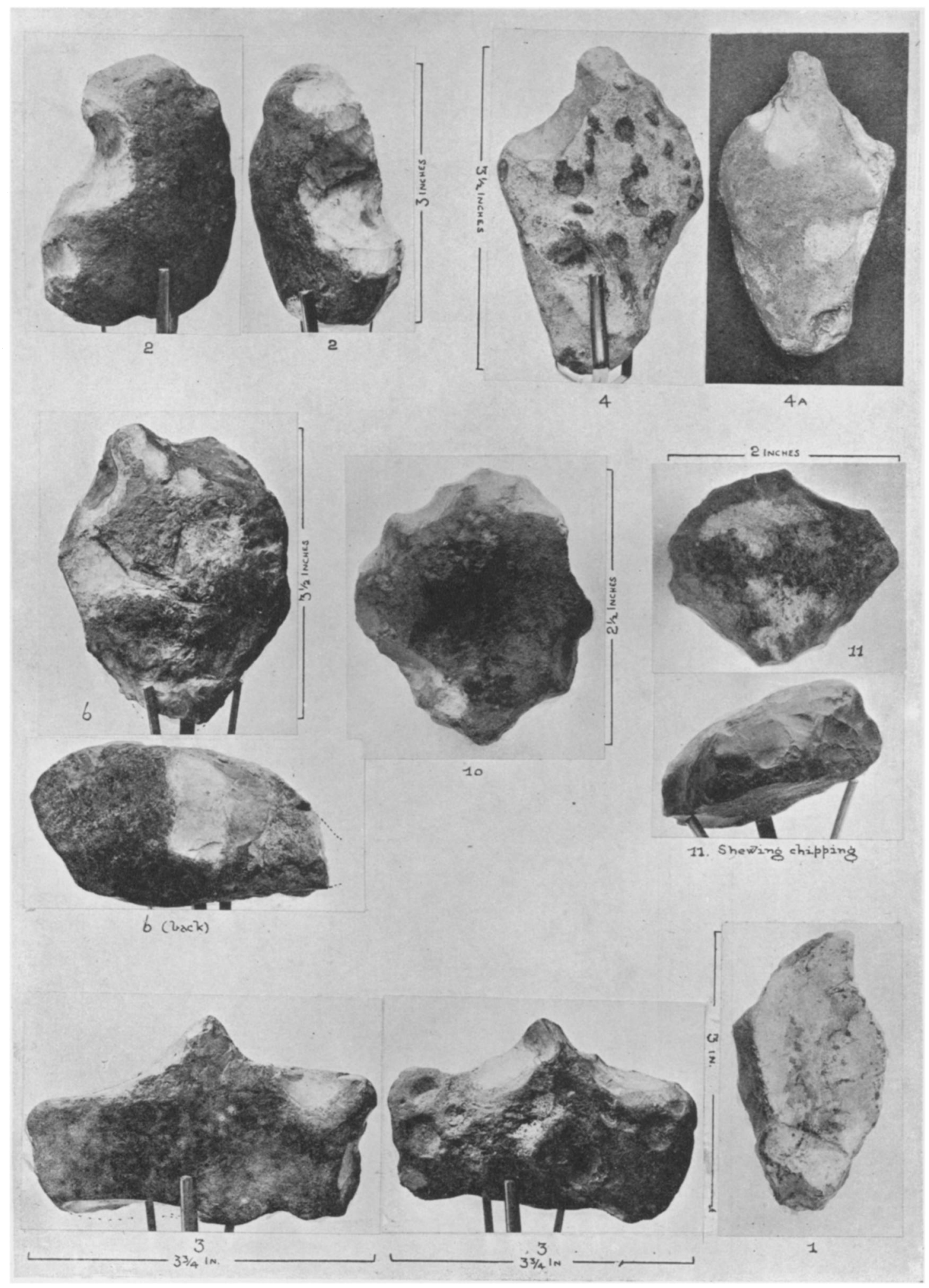

SOME EOLITHS FROM DEWLISH. 